\title{
ENHANCEMENT OF TENSILE STRENGTH OF LIGHTWEIGHT FOAMED CONCRETE THROUGH WOVEN FIBERGLASS MESH JACKETING
}

\author{
ANISAH MAT SERUDIN, MD AZREE OTHUMAN MYDIN \& ABDUL NASER ABDUL GHANI
}

School of Housing, Building and Planning, Universiti Sains Malaysia, 11800, Penang, Malaysia

Recently, the development of textile fabric as reinforcing element for concrete structure had gain attention by building component manufacturers. Many researchers reported that the confinement of concrete via textile fabric had showed a significant enhancement in concrete strength. They also highlighted that concrete with aggregate that less than $2 \mathrm{~mm}$ has great matrix-to-fibre bond. This information leads the authors to investigate the potential utilization of textile fabric as reinforcing element for Lightweight Foamed Concrete $($ LFC) since it utilizes fine aggregate with dimension that not more than $2 \mathrm{~mm}$. LFC has extremely low tensile strength due to its brittle nature. In this research paper, authors will reveal the assessment of splitting tensile strength of LFC strengthened with woven fiberglass mesh in order to change the typical brittle behaviour to elastic-plastic behaviour. The mix ratio applied in this research was fixed where the cement-to-sand ratio is 1:1.5 while water was maintained at 0.45. There are three designed densities were measured in this study which were $600 \mathrm{~kg} / \mathrm{m} 3,1100 \mathrm{~kg} / \mathrm{m} 3$, and $1600 \mathrm{~kg} / \mathrm{m} 3$. The $160 \mathrm{~g} / \mathrm{m} 2$ of woven fiberglass mesh was used as confinement material to the LFC, where the number of layer(s) employed being examined. The results show enhancements of 507\% (600 $\mathrm{kg} / \mathrm{m3}), 343 \%(1100 \mathrm{~kg} / \mathrm{m3})$, and $332 \%(1600 \mathrm{~kg} / \mathrm{m} 3)$ for tensile strength of LFC strengthened with woven fiberglass mesh compared to unreinforced LFC.
\end{abstract}

KEYWORDS: Foamed Concrete, Tensile Strength, Fibermesh, Textile Fabric, Confinement

Received: Jun 08, 2020; Accepted: Jun 28, 2020; Published: Aug 29, 2020; Paper Id.: IJMPERDJUN2020963

\section{INTRODUCTION}

Nowadays, sustainable development is increasingly in demand within the building and construction industry. A lot of studies have been conducted to fulfil this demand. The potential use of lightweight foamed concrete (LFC) in the construction industry is of growing interest among researchers. However, LFC is a brittle material that needs reinforcement to increase its strength, ductility, and toughness to delay structural failure. The use of steel reinforcement in LFC results in corrosion problems, which will affect its long-term durability, and will require maintenance at a high cost. In addition, steel reinforcement also increases with the weight of the structure.

According to Cibulka et al. (2019), lightweight concrete can be specially reinforced using grid shaped fibres also known as textile fabric. Yin et al. (2017) also stated that fine-grained concrete can be chosen to accomplish good bonding between the textile fabric and matrix. Besides, Dalal et al. (2017) also highlighted that fluid concrete with a maximum aggregate size of less than $2 \mathrm{~mm}$ is needed to provide sufficient binding, and to allow the load of the matrix to be transferred to the reinforcement. Therefore, the combination of LFC (produced by using fine aggregate/sand) and textile fabric can produce a lightweight and thin concrete element with a high load-bearing capacity. Nevertheless, Portal et al. (2017) stated that textile-reinforced concrete (TRC) has been coined as a versatile high-performance composite material, but it has not been sufficiently acknowledged due to the lack of design specifications. 
As mentioned by Gayathri et al. (2018), many researchers have been working with the idea of improving the performance of concrete by developing high-performance fibres, namely, TRC. They also explained that TRC is a type of reinforced concrete in which the fabric cage is utilized as a tensile reinforcing material in concrete. Volkova et al. (2016) also reported that reinforced concrete with high-strength textile fabrics (carbon and glass) has a greater residual loadbearing capacity, and is thus able to maintain the integrity of a structure after exposure to the maximum applied load. They also highlighted that the strength of concrete reinforced with carbon and glass textile fabrics is significantly increased compared to unreinforced concrete.

Comparative studies have been conducted to discover the influence of textile fabrics and short fibres as reinforcing elements in a cement matrix. According to a study by Peled and Mobasher (2005) on the tensile strength of a cement matrix reinforced with glass fabric and glass fibre (same cement matrix), the woven reinforcement provided a superior tensile strength. When subjected to a load, the textile fabric exhibited a better performance than the composite reinforced with short fibres (Boisse et al., 2005). This phenomenon was discussed by Dalal et al. (2017), who showed that the low strength of the short fibres due to the lack of arrangement in the matrix caused some of the fibres to be positioned perpendicular to the direction of the applied load. Thus, the application of a textile fabric can address this problem since the direction (position) of the reinforcement in the cement matrix can be adjusted to the desired design besides increasing the load-bearing capacity of the structure. Hence this study is conducted to observe the potential use of woven fiberglass mesh confinement of splitting tensile strength of Lightweight Foamed Concrete (LFC).

\section{LITERATURE REVIEW}

According to Neville (2011), the tensile strength is correlated to the compressive strength, although this relationship depends on multiple factors such as the aggregate type and particle size distribution, the age of the concrete, the curing process, and the air content. Besides, Thakrele (2014) reported that the tensile strength of LFC can be as high as 0.24 times its compressive strength, with an ultimate strain of about 0.1\%. Parra and Gomez (2011) mentioned that the splitting tensile strength for self-compacting concrete is lower than normal vibrated concrete due to the absence of aggregate-paste bonds in the matrix. Moreover, Amran et al. (2015) posited that the factors influencing compressive strength will equally affect the tensile strength and vice versa. Additionally, the proportion of flexural strength to axial compressive strength is around zero when LFC is designed with a density that is below $300 \mathrm{~kg} / \mathrm{m} 3$. Table 1 shows the splitting tensile strength results from a lower to a higher density, as examined by Jalal et al. (2017).

Table 1: Results of Splitting Tensile Strength from a Lower to a Higher Density (Jalal et al., 2017)

\begin{tabular}{|c|c|}
\hline Density $\left(\mathbf{k g} / \mathbf{m}^{\mathbf{3}}\right)$ & Splitting tensile strength $\left(\mathbf{N} / \mathbf{m m}^{\mathbf{2}}\right)$ \\
\hline 400 & 0.10 \\
\hline 500 & 0.20 \\
\hline 600 & 0.30 \\
\hline 700 & 0.35 \\
\hline 800 & 0.45 \\
\hline 900 & 0.55 \\
\hline 1000 & 0.65 \\
\hline 1200 & 1.10 \\
\hline 1400 & 1.20 \\
\hline 1800 & 1.60 \\
\hline
\end{tabular}


Kearsley (1999) mentioned that LFC is claimed to be weak and non-durable, with high shrinkage behaviour, and it should not be exposed to an aggressive atmosphere, where the unprotected reinforcement applied in LFC would be vulnerable to corrosion, even when the external attack is not very severe. Therefore, many studies have been carried out to improve the behaviour and performance of LFC. One such method is the inclusion of fibres in the mortar paste. The fibres are used to modify the tensile and flexural strengths, toughness, impact resistance, and fracture energy to arrest the formation and propagation of cracks, thereby improving the strength and ductility of LFC (Ahmad et al., 2010; Aydin, 2013; Bagherzadeh et al., 2012; Nahhas, 2013). Chandramouli et al. (2010) also proved that the inclusion of glass fibres improves the strength of the material by increasing the force required for deformation, and enhances the toughness by increasing the energy required for crack propagation. In addition, Ibrahim et al. (2014) explained that the flexural strength of LFC can be improved by introducing fibres into the matrix, where the progressive bending of the fibres slows down the propagation of cracks. Besides, Ranjbar et al. (2016) reported that when LFC expands under a bending load, thereby leading to cracking, the crack has a restricted distance over which it can spread before reaching the fibres, where it is prevented from growing.

Textile fabrics are used as reinforcement in concrete (Gayathri et al., 2018). This material was developed as an alternative to overcome the drawbacks of fibre-reinforced polymer (FRP), which are mainly associated with the use of epoxy resins (high cost, poor performance in high temperatures, inability to be applied on wet surfaces, and incompatibility with substrates such as concrete or masonry) (Koutas et al., 2019). Al-Gemeel and Zhuge (2018) verified that FRP materials have poor pore resistance, and the organic polymer rubble is classified as a hazardous material with poor information having been established on its disposal. Therefore, to alleviate the problems arising from FRP materials, textile fabrics were developed as a reinforcing element in concrete structures.

The first textile-based composite material was produced in Europe, and it is known as textile reinforced concrete (TRC) or textile reinforced mortar (TRM). It should be strictly noted that the inorganic matrix is not classified as concrete due to the very small size of the aggregates, while in the US, the materials are called fabric reinforced cementitious matrix (FRCM) systems (Koutas et al., 2019). Textile fabrics have gained attention due to their significant advantages, which are their high strength-to-weight ratio, ability to be manufactured in complex shapes, non- corrosive nature, and low thermal conductivity (Karaduman et al., 2017). Many studies have been conducted to investigate the mechanical properties of textile fabric reinforcements, and the major materials that have been utilized in civil engineering are carbon, glass, and basalt.

\section{Mix Composition and Experimental Setup}

To investigate the effects of woven fiberglass mesh in LFC, three different densities were designed which were $600 \mathrm{~kg} / \mathrm{m} 3$, $1100 \mathrm{~kg} / \mathrm{m} 3$, and $1600 \mathrm{~kg} / \mathrm{m} 3$. These densities represent as non- structural, semi-structural, and structural building elements for the respective density. Besides, the number of layer(s) employed also being analysed to studied more detailed about its effect to the LFC. $160 \mathrm{~g} / \mathrm{m} 2$ of woven fiberglass mesh was selected due to its advantages such as low self- weight, alkali resistant, flexible, durable, and cheaper than other material (carbon, steel, etc).

In order to get the comparable results, the mix ratio for this research was fixed to 1:1.5 (cement-to-sand) ratio and water constant at 0.45 . The cement used was Type 1 Portland cement which was applied according to ASTM C150-04 (2004). Fine sand with dimension size is less than $1.18 \mathrm{~mm}$ was selected as a filler to produce LFC. As highlighted by Nambiar and Ramamurthy (2006), the fine sand produced better strength in LFC as the use of coarse sand in a compound 
matrix cause the pores to become bigger and create an inconsistent mix. Clean water was used to bind the cement and filler through the process of hydration, thereby causing the hardening of the mortar paste. Besides, an important ingredient in producing the LFC is the foaming agent where the protein-based agent was chosen. Fig. 1 and 2 show the position of woven fiberglass mesh confining the LFC.

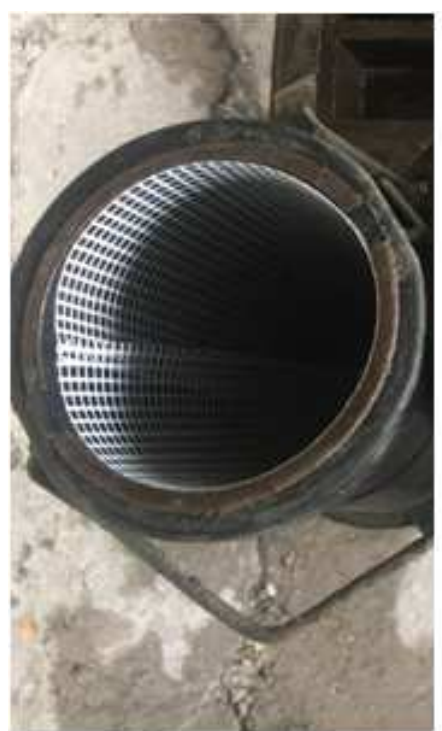

(a) 1 layer

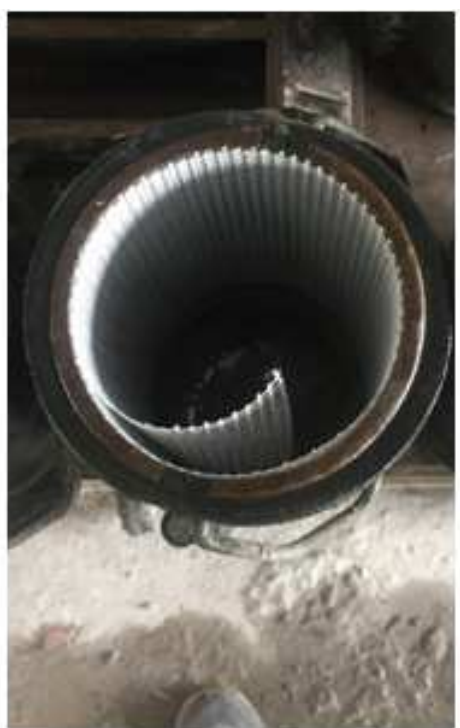

(b) 2 layers

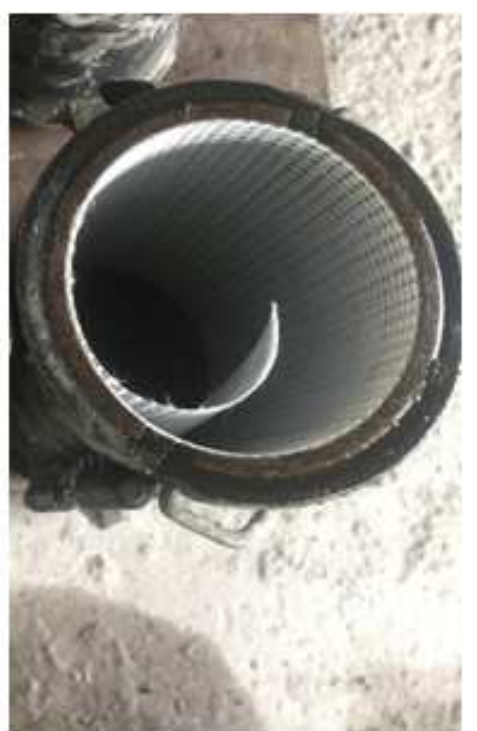

(c) 3 layers

Figure 1: Woven Fiberglass Mesh was Cut to Fit into the Mould.

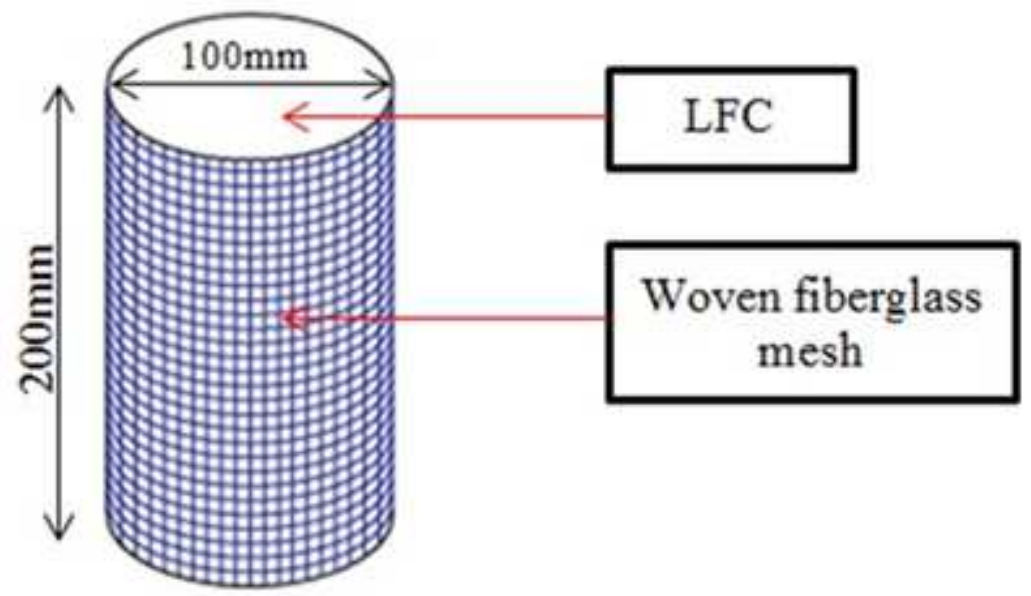

Figure 2: Woven Fiberglass Mesh Confining the Specimen all Around.

The tensile strength of concrete can be determined by the application of a direct tensile stress or indirect tensile strength. In this study, the indirect tensile strength was applied, according to ASTM C496/C496M (2004) standard. A Universal Testing Machine (GTECH GT- 7001-BS300) was used to perform the splitting tensile test. Three cylindrical specimens measuring $100 \varnothing \mathrm{mm}$ x $200 \mathrm{~mm}$ were tested at day-7, day-28, day-56 and day-180, and the average value at each tested day was recorded as the final result of the splitting tensile test. Equation 1 was used to determine the splitting tensile strength, while the setup for this test is shown in Fig. 3. In this test, also known as the Brazilian test, the indirect tensile strength obtained is related to the compressive strength, water-to-cement ratio, and age of the concrete, and it is useful for experiments with brittle materials, where the compressive strength is higher compared to the tensile strength. 
Equation 1

Where, $\mathrm{P}=$ Maximum Load Carried by Specimen, L = Length of Specimen, $\mathrm{D}=$ Diameter of Specimen

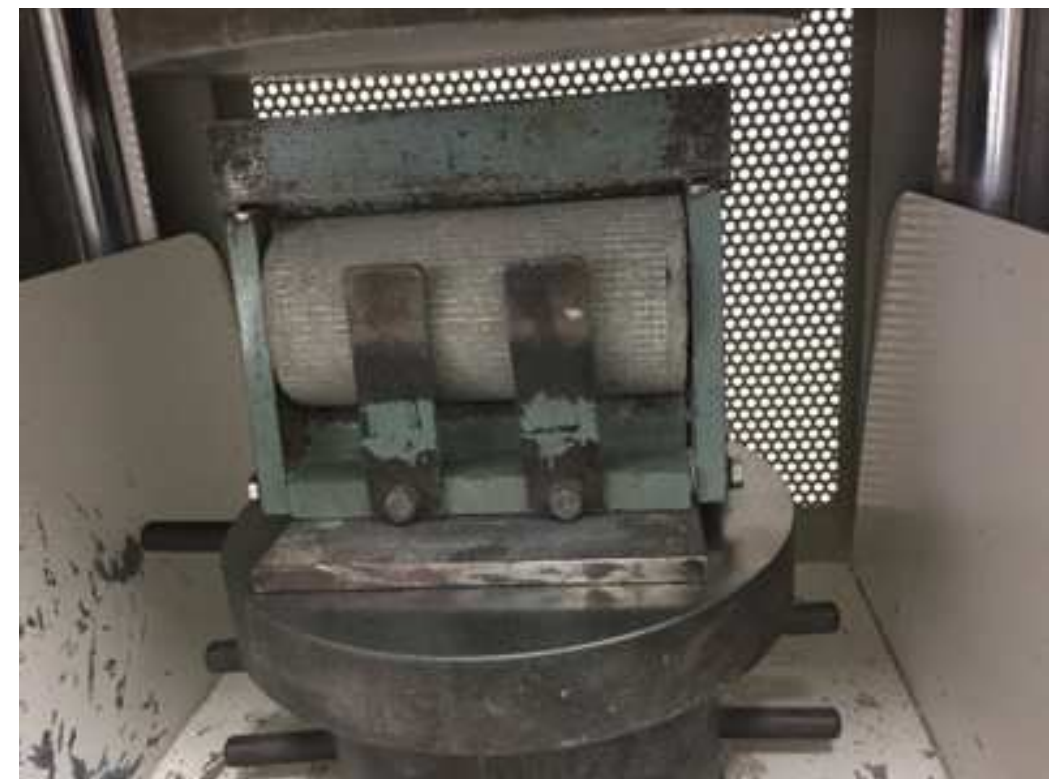

Figure 3: Setup for Splitting Tensile Strength Test.

\section{RESULTS AND DISCUSSION}

As reported by Amran et al. (2015), the factors that influence compressive strength equally affect the tensile strength of LFC. Thus, unconfined LFC, which is brittle, possesses a lower tensile strength. This was proven by the results of the splitting tensile strength obtained in this study, which showed a similar trend as that of the compressive strength, as shown in Fig. 4, Fig. 5, and Fig. 6. These three figures demonstrated that the tensile strength of the unconfined and confined LFC grew increasingly as the curing age progressed. The volume of foam also significantly affected the tensile strength. For instance, the tensile strength obtained for the control specimen with a density of $600 \mathrm{~kg} / \mathrm{m}^{3}$ at day-180 was $0.14 \mathrm{~N} / \mathrm{mm} 2$, and this tensile strength then increased by $229 \%$ after the foam volume was reduced to obtain the desired density of 1100 $\mathrm{kg} / \mathrm{m} 3$. An increase of $122 \%$ in the tensile strength was also achieved for the LFC specimens with a density of $1600 \mathrm{~kg} / \mathrm{m} 3$ as only a small amount of foam was needed to achieve this preferred density compared to a density of $1100 \mathrm{~kg} / \mathrm{m} 3$. However, the results of the tensile strength obtained for the control specimens were considered to be low due to the absence of a reinforcing element in the matrix. Thus, the confinement of LFC with different number of layers of woven fiberglass mesh improved the performance of the LFC in terms of its tensile strength.

The significant enhancement of the tensile strength of the LFC specimens confined with different number of layers of woven fiberglass mesh is illustrated in Table 2. When the LFC was wrapped in 1 layer of woven fiberglass mesh, the tensile strength increased by $186 \%, 157 \%$, and $150 \%$ for the specimens with densities of $600 \mathrm{~kg} / \mathrm{m} 3,1100 \mathrm{~kg} / \mathrm{m}^{3}$, and $1600 \mathrm{~kg} / \mathrm{m}^{3}$, respectively, compared to the unconfined specimens. For the confinement with 2 layers of woven fiberglass mesh, the increases in the tensile strength, which were $279 \%, 237 \%$ and $234 \%$ for the respective densities, were double those of the specimens confined with 1 layer of textile fabric. Superior augmentations of 507\%, 343\%, and 332\% in tensile strength were accomplished when the LFC specimens with densities of $600 \mathrm{~kg} / \mathrm{m}^{3}, 1100 \mathrm{~kg} / \mathrm{m}^{3}$, and $1600 \mathrm{~kg} / \mathrm{m}^{3}$, respectively were confined with 3 layers of woven fiberglass mesh. 
The incredible enhancement of the tensile strength in LFC proves that woven fiberglass mesh has the potential to be used as a reinforcing element in LFC. This performance also improved as the number of layers of textile fabric for the confinement was increased. The woven fiberglass mesh used in this study not only had strong fibre-to-matrix bonding, but also exceptionally strong fibre-to-fibre bonding, which enabled stretching and prevented the LFC from collapsing. As highlighted by Parveen and Sharma (2013), the enhancement of tensile strength is due to the holding capacity of the fibres, which can aid in the splitting of the concrete.

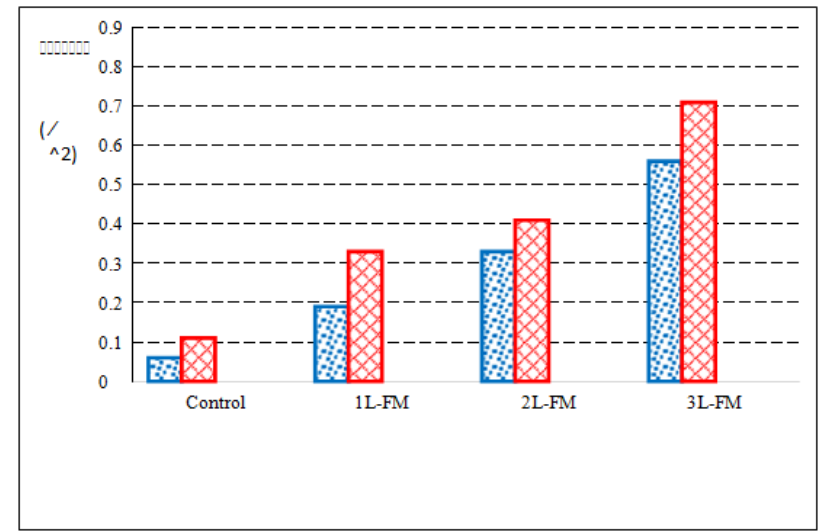

Figure 4: Tensile Strength of LFC Specimens with a Density of $600 \mathrm{~kg} / \mathrm{m}^{3}$ Confined with Different Number of Layers of $160 \mathrm{~g} / \mathrm{m}^{2}$ of Woven Fiberglass Mesh.

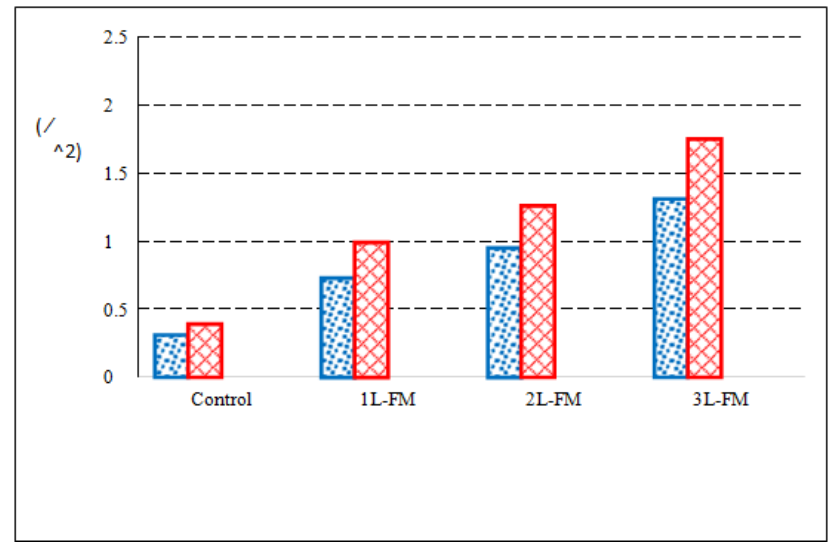

Figure 5: Tensile Strength of LFC Specimens with a Density of $1100 \mathrm{~kg} / \mathrm{m}^{3}$ Confined with Different Number of Layers of $160 \mathrm{gm}^{2}$ of Woven Fiberglass Mesh.

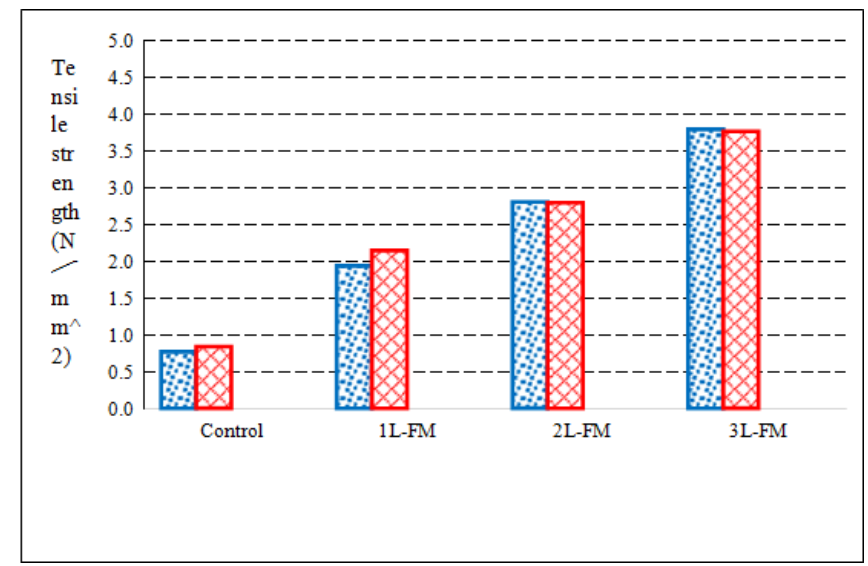

Figure 6: Tensile Strength of LFC Specimens with a Density of $1600 \mathrm{~kg} / \mathrm{m}^{3}$ Confined with Different Number of Layers of $160 \mathrm{gm}^{2}$ of Woven Fiberglass Mesh. 
Table 2: Percentage Increase in Tensile Strength of LFC Specimens Confined with 1 Layer, 2 Layers, and 3 Layers of Woven Fiberglass Mesh at Three Different Densities Compared to the Control

Specimens at Day-180

\begin{tabular}{|c|c|c|c|}
\hline \multirow{2}{*}{ Specimen } & \multicolumn{3}{|c|}{ Percentage increase $(\%)$} \\
\hline & $600 \mathrm{~kg} / \mathrm{m}^{3}$ & $1100 \mathrm{~kg} / \mathrm{m}^{3}$ & $1600 \mathrm{~kg} / \mathrm{m}^{3}$ \\
\hline 1L-FM & 186 & 157 & 150 \\
\hline 2L-FM & 279 & 237 & 234 \\
\hline 3L-FM & 507 & 343 & 332 \\
\hline
\end{tabular}

Fig. 7 shows the failure modes of LFC under tension loading. When the control specimen reached its maximum applied load during the testing, it was broken into two pieces by a vertical crack (refer to Fig. 7 (a)). This was caused by the brittleness of the LFC, which failed to resist the crack propagation. For the confined LFC, as shown in Fig. 7 (b), (c), and (d), only a small crack appeared at the top surface of the specimens and a vertical mark at the lateral surface. The specimens did not break into two even after the failure due to the confinement with woven fiberglass mesh, which arrested the occurrence of a major crack. Therefore, this supported the previous statement that the technique of jacketing the LFC in woven fiberglass mesh increased its tensile strength compared to the unconfined specimens.

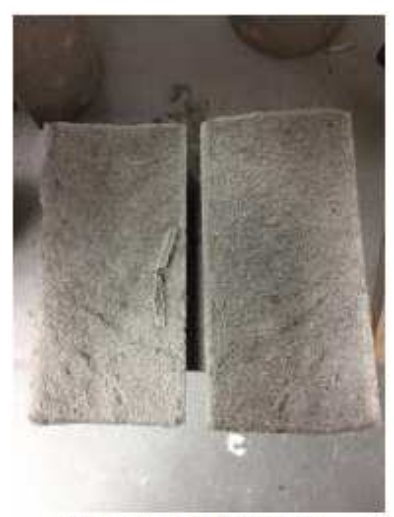

(a) Control specimen

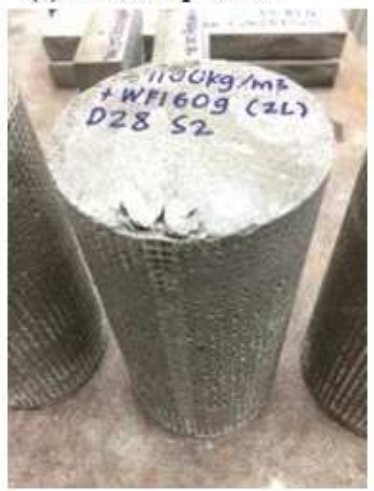

(c) 2 layers of woven fiberglass mesh

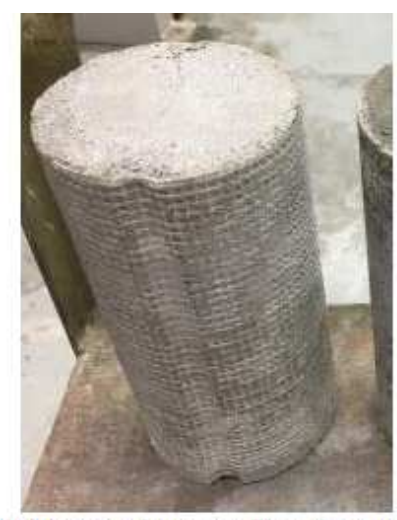

(b) 1 layer of woven fiberglass mesh

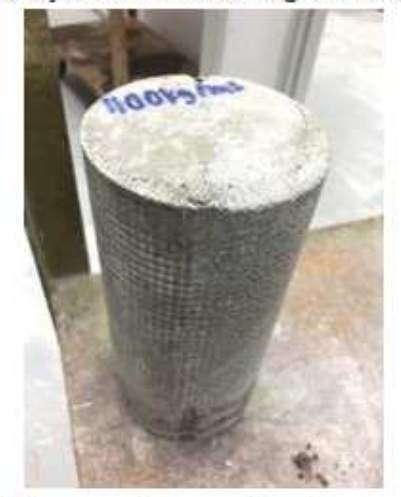

(d) 3 layers of woven fiberglass mesh

Figure 7: Failure Modes of LFC Under Tension Loading.

\section{CONCLUSIONS}

From this study, the superior enhancement of the LFC specimens wrapped with different number of layers of woven fiberglass mesh was achieved for the splitting tensile strength test. The maximum tensile strength values obtained were $0.85 \mathrm{~N} / \mathrm{mm} 2,2.04 \mathrm{~N} / \mathrm{mm} 2$, and $4.41 \mathrm{~N} / \mathrm{mm} 2$ with enhancements of $186 \%$ to $567 \%, 157 \%$ to $343 \%$, and $150 \%$ to $332 \%$, respectively for the various densities. Hence, this demonstrated that the strengthening of LFC with woven fiberglass mesh enhanced its splitting tensile strength. 


\section{REFERENCES}

1. Ahmad, Z., Saman, H. M., \& Tahir, P. M. (2010). Oil Palm Trunk Fiber as a Bio-Waste Resource for Concrete Reinforcement. International Journal of Mechanical and Materials Engineering (IJMME), 5(2), 2010. Retrieved from https://pdfs.semanticscholar.org/32f1/2cff145c9ae23babf64e9c6e49dae39fce05.pdf

2. Al-Gemeel, A. N., \& Zhuge, Y. (2018). Axial performance of textile reinforced composite tubes under compression. International Journal of Civil Engineering and Technology, 9(7), 809-823. Retrieved from https://ascelibrary.org/doi/pdf/10.1061/\%28ASCE\%29CC.1943-5614.0000882

3. Amran, Y. H. M., Farzadnia, N., \& Ali, A. A. A. (2015). Properties and applications of foamed concrete; A review. Construction and Building Materials, 101(December), 990-1005. https://doi.org/10.1016/j.conbuildmat.2015.10.112

4. ASTM C150-04. (2004a). Standard Specification for Portland Cement C150-04. Annual Book of ASTM Standards, 04(02), 18.

5. ASTM C496/C496M-04. (2004b). Standard Test Method for Splitting Tensile Strength of Cylindrical Concrete Specimens C496/C496M-04. Annual Book of ASTM Standards. https://doi.org/10.1520/C0496

6. Al-Ameen, Ehsan Sabah, and Mohammed Husam Tawfeeq. "The Effect of Internal Pressure and Temperature on Hoop Strain Behavior in Spherical Composite Shell." International Journal of Mechanical and Production Engineering Research and Development, (IJMPERD) ISSN (P) (2018): 2 249-6890.

7. Aydin, S. (2013). Effects of fiber strength on fracture characteristics of normal and high strength concrete. Periodica Polytechnica Civil Engineering, 57(2), 191-200. https://doi.org/10.3311/PPci.7174

8. Bagherzadeh, R., Pakravan, H. R., Sadeghi, A. H., Latifi, M., \& Merati, A. A. (2012). An investigation on adding polypropylene fibers to reinforce lightweight cement composites (LWC). Journal of Engineered Fibers and Fabrics, 7(4), 1321. https://doi.org/10.1177/155892501200700410

9. Boisse, P., Gasser, A., Hagege, B., \& Billoet, J. L. (2005). Analysis of the mechanical behavior of woven fibrous material using virtual tests at the unit cell level. Journal of Materials Science, 40(22), 5955-5962. https://doi.org/10.1007/s10853-005$5069-7$

10. Chandramouli, K., Srinivasa, R. P., Pannirselvam, N., Seshadri, S. T., \& Sravana, P. (2010). Strength properties of glass fibre concrete. Journal of Engineering and Applied Sciences, 5(4), 1-6. Retrieved from http://www.arpnjournals.com/jeas/research_papers/rp_2010/jeas_0410_318.pdf

11. Cibulka, T., Musil, L., \& Vodička, J. (2019). The Lightweight Textile Reinforced Concrete for Thin-Walled Structures. Acta Polytechnica CTU Proceedings, 22, 17-21. https://doi.org/10.14311/app.2019.22.0017

12. Dalal, M., Goumairi, O., \& Malik, A. El. (2017). Study of the internal confinement of concrete reinforced (in civil engineering) with woven reinforcement. IOP Conference Series: Materials Science and Engineering, 254(4). https://doi.org/10.1088/1757$899 X / 254 / 4 / 042008$

13. Gayathri, C. N., Singh, R. B., \& Dhanalakshmi, G. (2018). Mechanical behaviour of textile reinforced concrete. International Research Journal of Engineering and Technology (IRJET), 5(5), 2227-2231. Retrieved from https://www.academia.edu/38216913/IRJET__Mechanical_Behaviour_of_Textile_Reinforced_Concrete

14. Ibrahim, M. H. W., Jamaludin, N., Irwan, J. M., Ramadhansyah, P. J., \& Hani, A. S. (2014). Compressive and flexural strength of foamed concrete containing polyolefin fibers. Advanced Materials Research, 911(March), $489-493$. https://doi.org/10.4028/www.scientific.net/AMR.911.489 
15. Jalal, M. D., Tanveer, A., Jagdeesh, K., \& Ahmed, F. (2017). Foam concrete. International Journal of Civil Engineering Research,8(1),1-14.Retrieved from https://www.ripublication.com/ijcer17/ijcerv8n1_01.pdf

16. Karaduman, N. S., Karaduman, T., Ozdemir, H., \& Ozdemir, G. (2017). Textile Reinforced Structural Composites for Advanced Applications. Textile for Advanced Applications, 89-133. https://doi.org/http://dx.doi.org/10.5772/57353

17. Kearsley, E. P. (1999). Just foamed concrete - an overview (R. K. Dhir \& N. A. Handerson, Eds.). London: Thomas Telford.

18. Koutas, L. N., Tetta, Z., Bournas, D. A., \& Triantafillou, T. C. (2019). Strengthening of Concrete Structures with Textile Reinforced Mortars: State-of-the-Art Review. Journal of Composites for Construction, 23(1), 1-20. https://doi.org/10.1061/(ASCE)CC.1943-5614.0000882

19. Manyam, Shiresha, and Padma Alapati. "Eco-Friendly Sisal Union Fabric-Suitability A ssesment." (2018). International Journal of Educational Science and Research (IJESR) 8,.3, Jun 2018, 77-84

20. Nahhas, T. M. (2013). Flexural Behavior and Ductility of Reinforced Lightweight Concrete Beams with Polypropylene Fiber. Journal of Construction Engineering and Management, 1(1), 4-10. Retrieved from http://researchpub.org/journal/jcem/number/vol1-no1/vol1-no1-1.pdf

21. Nambiar, E. K. K., \& Ramamurthy, K. (2006). Influence of filler type on the properties of foam concrete. Cement and Concrete Composites, 28(5), 475-480.

22. Neville, A. M. (2011). Properties of concrete (5th editio). Retrieved from https://igitgeotech.files.wordpress.com/2014/10/properties-of-concrete-by-a-m-neville.pdf

23. Parra, C. M., \& Gomez, F. (2011). Splitting tensile strength and modulus of elasticity of self- compacting concrete. Construction and Building Materials, 25, 201-207.

24. Parveen, \& Sharma, A. (2013). Structural behaviour of fibrous concrete using polypropylene fibres. International Journal of Modern Engineering Research, 3(3), 1279-1282. Retrieved from https://www.researchgate.net/profile/Parveen_Jangra/publication/303783435_Structural_behaviour_of_fibrous_concrete_usi ng_polypropylene_fibres/links/58b82c1f45851591c5d7efa8/Structural- behaviour-of-fibrous-concrete-using-polypropylenefibres.pdf

25. Parthiban, R., R. Sakthivel, and Srikanth Jetti. "Fabrication and Study of H Ardness Behaviour on Gamma Irradiated UltraHigh Molecular Weight P Olyethylene (UHMWPE) Plate." International Journal of Mechanical and Production Engineering Research and Development (IJMPERD) 8.2, Apr 2018, 45-52

26. Peled, A., \& Mobasher, B. (2005). Properties of fabric-cement composites made by pultrusion. Materials and Structures, 39(292), 787-797. https://doi.org/10.1617/s11527-006-9171-3

27. Portal, N. W., Thrane, L. N., \& Lundgren, K. (2017). Flexural behaviour of textile reinforced concrete composites: experimental and numerical evaluation. Materials and Structures, 50(4), 1-14. https://doi.org/10.1617/s11527-016-0882-9

28. Ranjbar, N., Behnia, A., Alsubari, B., Birgani, P. M., \& Jumaat, M. Z. (2016). Durability and mechanical properties of selfcompacting concrete incorporating palm oil fuel ash. Journal of Cleaner Production, 112, 72730.

29. Rout, ARUN KUMAR, and JITESH KUMAR Singh. "An Overview of Advanced Fiber R Einforced Polymer Composites and It's Applications." International Journal of Mechanical and Production Engineering Research and Development (IJMPERD) 8 (2018): 311-3 18 . 
30. Thakrele, M. H. (2014). Experimental study on foam concrete. International Journal of Civil, Structural, Environmental and Infrastructure Engineering Research and Development, 4(1), 145-158. Retrieved from http://www.tjprc.org/publishpapers/211-1394782454-17. Civil - IJCSEIERD --Experimental Study On Foam Concrete - Maheshkumar H. Thakrele - Paid Copy.pdf

31. Volkova, A., Paykov, A., Semenov, S., Stolyarov, O., \& Melnikov, B. (2016). Flexural Behavior of Textile-Reinforced Concrete. MATEC Web of Conferences, 53, 1-7. https://doi.org/10.1051/matecconf/20165301016

32. Yin, S., Wang, B., Wang, F., \& Xu, S. (2017). Bond investigation of hybrid textile with self-compacting fine-grain concrete. Journal of Industrial Textiles, 46(8), 1616-1632. https://doi.org/10.1177/1528083716629137 